\title{
Synthesis of an End-to-End Protein-Glycopolymer Conjugate via Bio-Orthogonal Chemistry
}

Hailong Zhang, Jacob Weingart, Valentinas Gruzdys, and Xue-Long Sun*

\section{SUPPORTING INFORMATION}

\section{Synthesis of $p$-Amido[tetra(ethylene glycol)]- $N$-dibenzylcyclooctynephenyl- $\beta$-D- galactopyranoside (DBCO-PEG ${ }_{4}-\mathrm{CONH}-\mathrm{Ph}-\boldsymbol{\beta}$-D-Gal)}

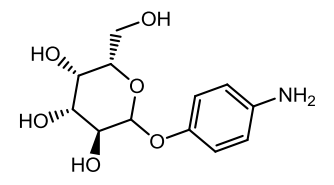

Molecular Weight: 271.27 p-Aminophenyl- $\beta$-D-galactose

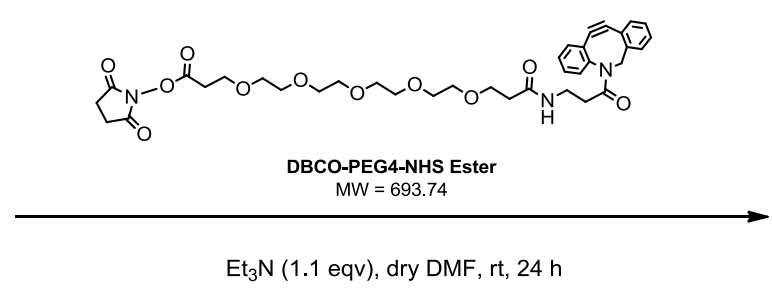

Scheme 1s. Synthesis of DBCO-PEG $4-\mathrm{CONH}-\mathrm{Ph}-\beta$-D-Gal

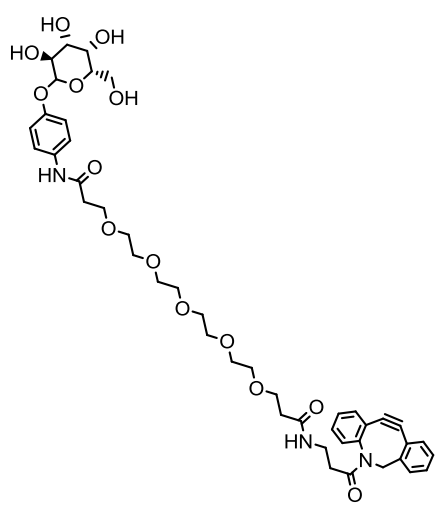

Molecular Weight: 849.92 DBCO-PEG 4 -CONH-Phenyl- $\beta$-D-Galactose

To a vial containing $3.2 \mathrm{mg}$ of $p$-aminophenyl- $\beta$-D-galactopyranoside and a stir bar, $0.1 \mathrm{~mL}$ $\mathrm{Et}_{3} \mathrm{~N}$ was added and the reaction mixture was then allowed to stir for 15 min at room temperature. After $15 \mathrm{~min}$, then a $1 \mathrm{~mL}$ solution of dry DMF containing $9 \mathrm{mg}$ (1.1 eqv) DBCOPEG4-NHS ester was added via syringe. The vial was then flushed with $\mathrm{N}_{2}(\mathrm{~g})$ and capped to stir at room temperature for $24 \mathrm{~h}$. The reaction prior to work up was checked by TLC 1:4 $\mathrm{MeOH} / \mathrm{CHCl}_{3}$ against the starting materials to confirm reaction completion. Then the solvent in the vial was reduced to near dryness under vacuum. The residue was then chromatographed on silica gel using 1:4 $\mathrm{MeOH} / \mathrm{CHCl}_{3}$ solution as eluent. The isolated compound, exhibiting longwave UV-Vis fluorescence $\left(\mathrm{R}_{\mathrm{f}} \sim 0.45,1: 4 \mathrm{MeOH} / \mathrm{CHCl}_{3}\right)$, was collected and reduced to dryness achieving DBCO-PEG4-CONH-phenylgalactose (4.7 mg, 47\%). ${ }^{1} \mathrm{H}$ NMR $\left(\mathrm{CDCl}_{3}, 300 \mathrm{MHz}\right) \delta$ : 7.64 (d, 1H, H-Ar of DBCO), 7.46 - 7.34 (m, 12H, H-Ar of DBCO and Ph), 7.24 (d, 1H, H-Ar of DBCO), 7.06 (d, 2H, H-Ph), 5.11 (d, 1H, H1-Gal), 4.84 (d, 2H, $\mathrm{CH}_{2}$ of DBCO), 3.92 (s, 1H, H- 
Gal), 3.80-3.47 (m, 5H, H-Gal), 3.55 (s, 16H, $\mathrm{CH}_{2}$-PEG), 3.23 (m, 1H), 3.09 (m, 1H), 2.92 (m, 1H), $2.60\left(\mathrm{t}, 4 \mathrm{H}, \mathrm{CH}_{2} \mathrm{COx} 2\right), 2.42(\mathrm{~m}, 1 \mathrm{H}), 2.27(\mathrm{~m}, 2 \mathrm{H}), 2.02(\mathrm{~m}, 1 \mathrm{H})$. FTIR $\left(\mathrm{cm}^{-1}\right)$ : 3341, $3066(\mathrm{C} \equiv \mathrm{C}), 2875,2486(\mathrm{C} \equiv \mathrm{C}), 1715,1646$, 1508, 1456, 1397, 1226, 1076, 832. ESI-MS: $851.2778(\mathrm{M}+\mathrm{H})^{+}, 873.2689(\mathrm{M}+\mathrm{Na})^{+}$.

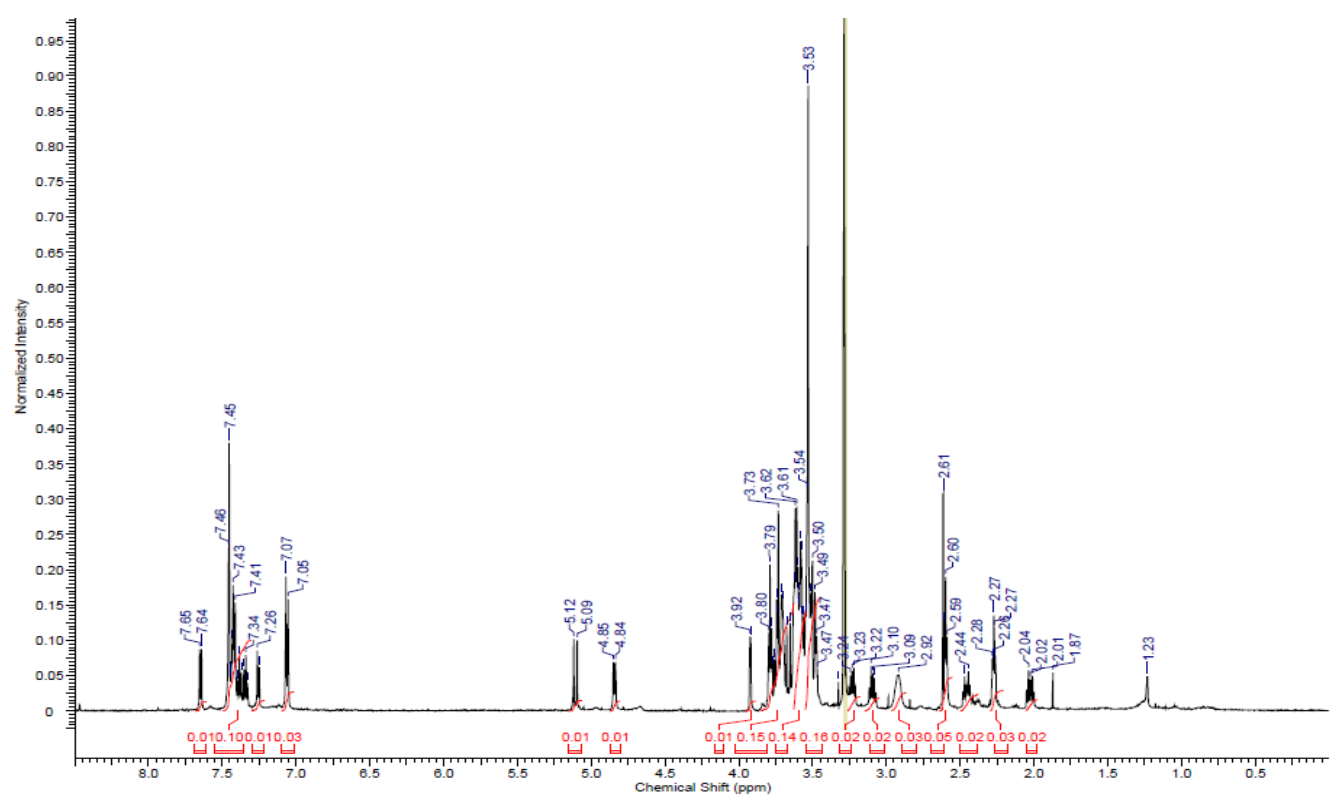

Figure 2s. ${ }^{1} \mathrm{H}$ NMR spectrum $\left(\mathrm{CD}_{3} \mathrm{OD}\right.$, w/ 1-2 dps $\left.\mathrm{D}_{2} \mathrm{O}\right)$ of DBCO-PEG 4 -CONH-Ph- $\beta$-D-Gal

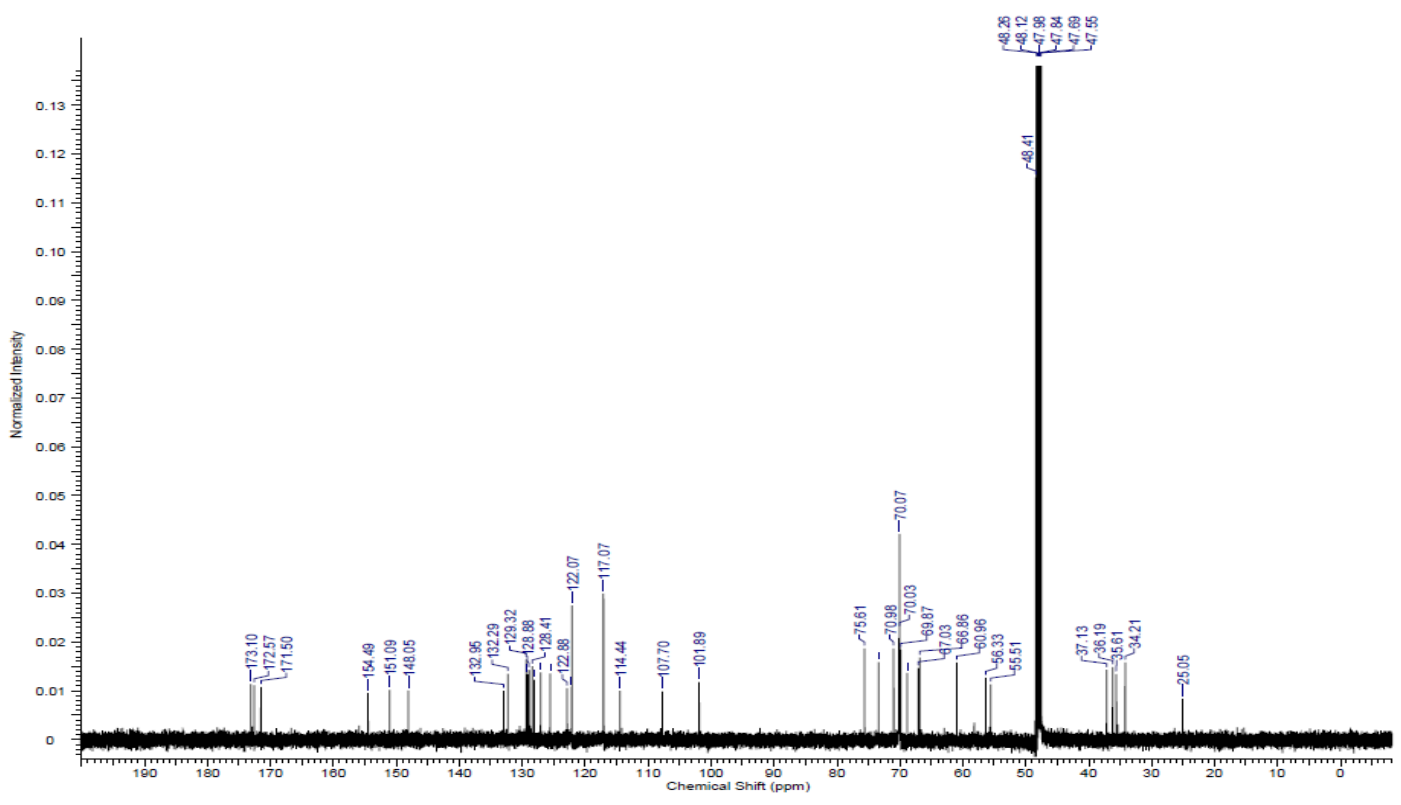

Figure 2s. ${ }^{13} \mathrm{C}$ NMR Spectrum $\left(\mathrm{CD}_{3} \mathrm{OD}\right.$, w/ 1-2 dps $\left.\mathrm{D}_{2} \mathrm{O}\right)$ of $\mathrm{DBCO}-\mathrm{PEG}_{4}-\mathrm{CONH}-\mathrm{Ph}-\beta$-D-Gal 


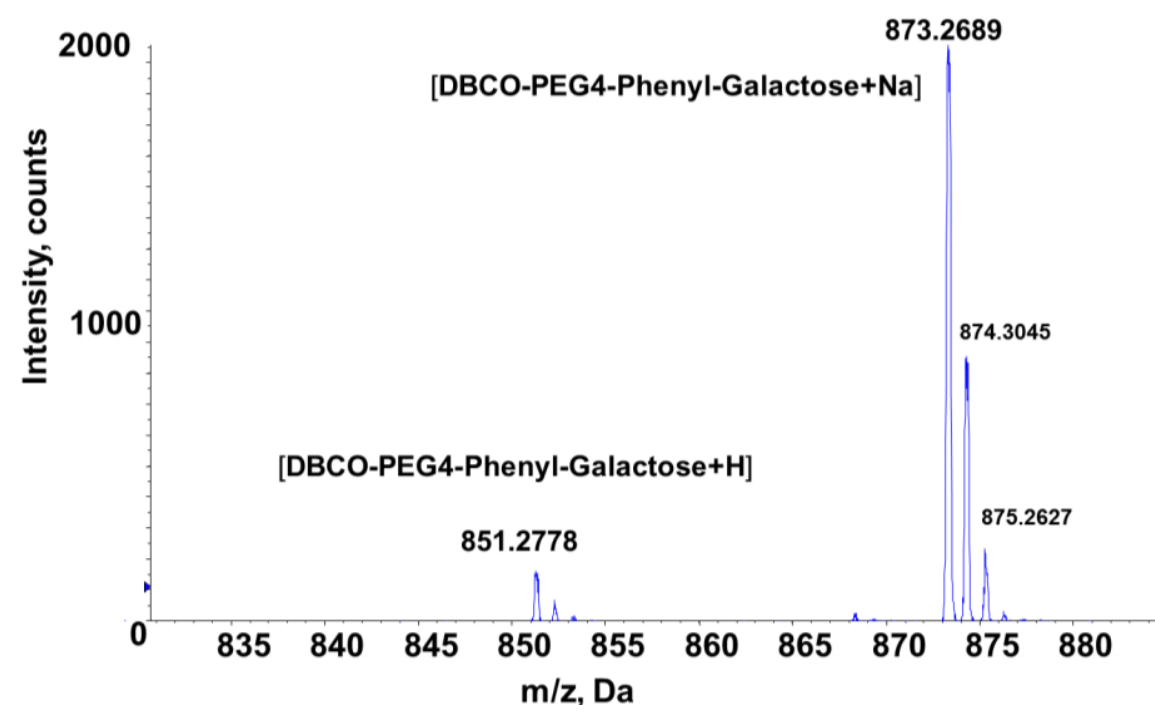

Figure 3s. ESI-MS spectrum of DBCO- $\mathrm{PEG}_{4}-\mathrm{CONH}-\mathrm{Ph}-\beta$-D-Gal. Mass spectrometry experiments were performed using QSTAR Elite mass spectrometer (Applied Biosystems, Foster City, CA). Data was conducted with Analyst ${ }^{\circledR}$ QS 2.0 software.

\section{Synthesis of DBCO-functionalized glycopolymer}

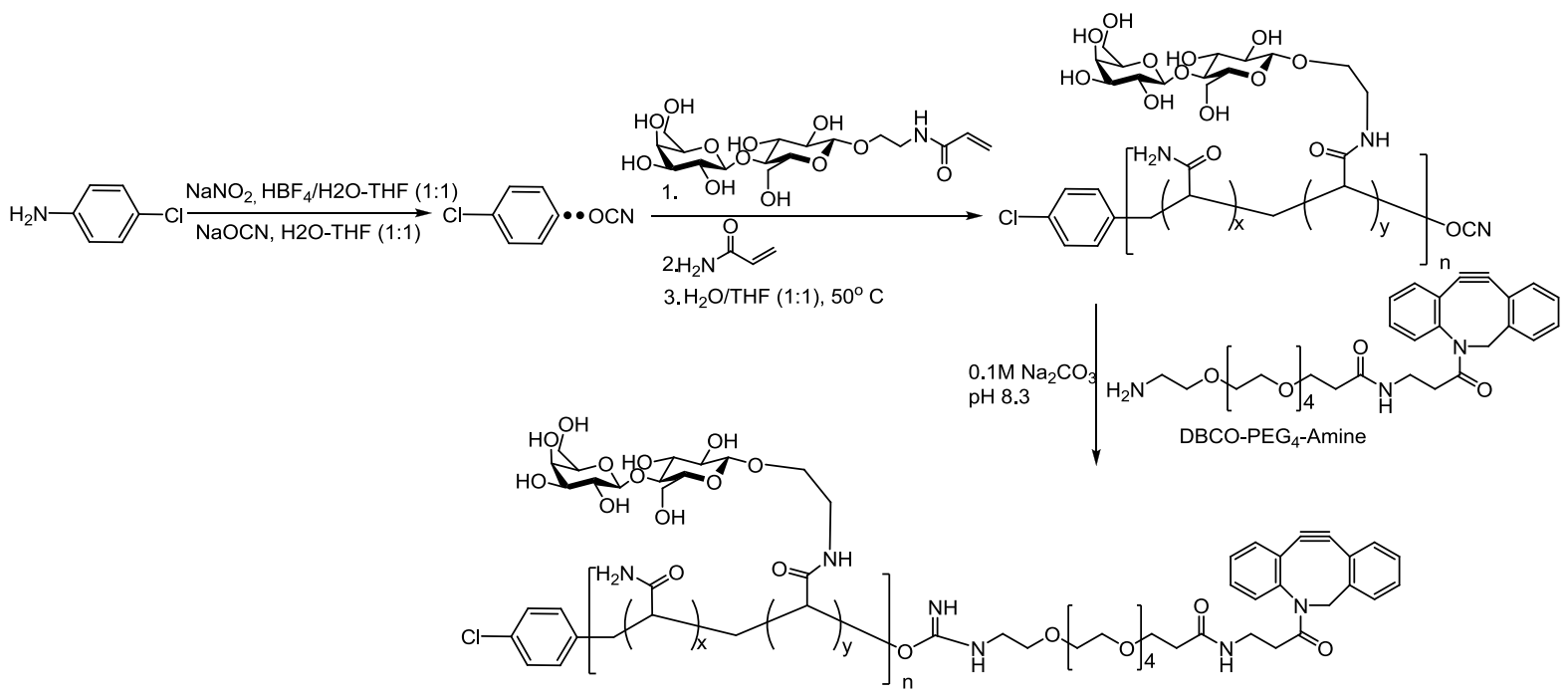

Scheme 2s. Synthesis of DBCO-functionalized glycopolymer

First, lactose-based $O$-cyanate chain-end functionalized glycopolymer was synthesized from a lactose acrylamide derivative via cyanoxyl mediated free radical polymerization in previously reported method ${ }^{[1]}$ Briefly, sodium nitrite $(7 \mathrm{mg}, 1.0 \mathrm{mmol})$ and 4-chloroaniline $(11 \mathrm{mg}, 0.09$ 
mmol) was dissolved in $3 \mathrm{ml}$ mixture of $\mathrm{H}_{2} \mathrm{O} / \mathrm{THF}(1: 1, \mathrm{~V} / \mathrm{V})$, followed by adding $\mathrm{HBF}_{4}(122 \mathrm{mg}$, $1.5 \mathrm{mmol}$ ) to incubate for 30mins. Next, acrylated lactose monomer (90 mg, $13 \mu \mathrm{mol}) \mathrm{NaOCN}$ (27 mg, $0.42 \mathrm{mmol}$ ) and acryamide (105 mg, $13 \mu \mathrm{mol}$ ) was added sequently and incubated over $16 \mathrm{~h}$ at $60{ }^{\circ} \mathrm{C}$, followed by dialysis (3500 Da MW cutoff) to afford lactose based $O$-cyanate chain-end gylcopolymer (275 mg, $65 \%)$.

Then, DBCO Functionalized glycopolymer was synthesized directly from the lactose-based $O$-cyanate chain-end functionalized glycopolymer by dissolving $50 \mathrm{mg}$ in $0.1 \mathrm{M}$ sodium

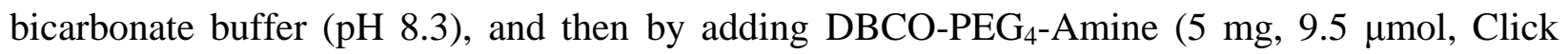
Chemistry Tools) dissolved in $200 \mu \mathrm{L}$ DMSO slowly. The mixture was allowed to stir for $12 \mathrm{~h}$ at room temperature, followed by dialysis (3500 Da MW cutoff) to remove unreacted DBCO$\mathrm{PEG}_{4}$-Amine affording the DBCO-PEG 4 -glycopolymer (35 mg, 70\%).

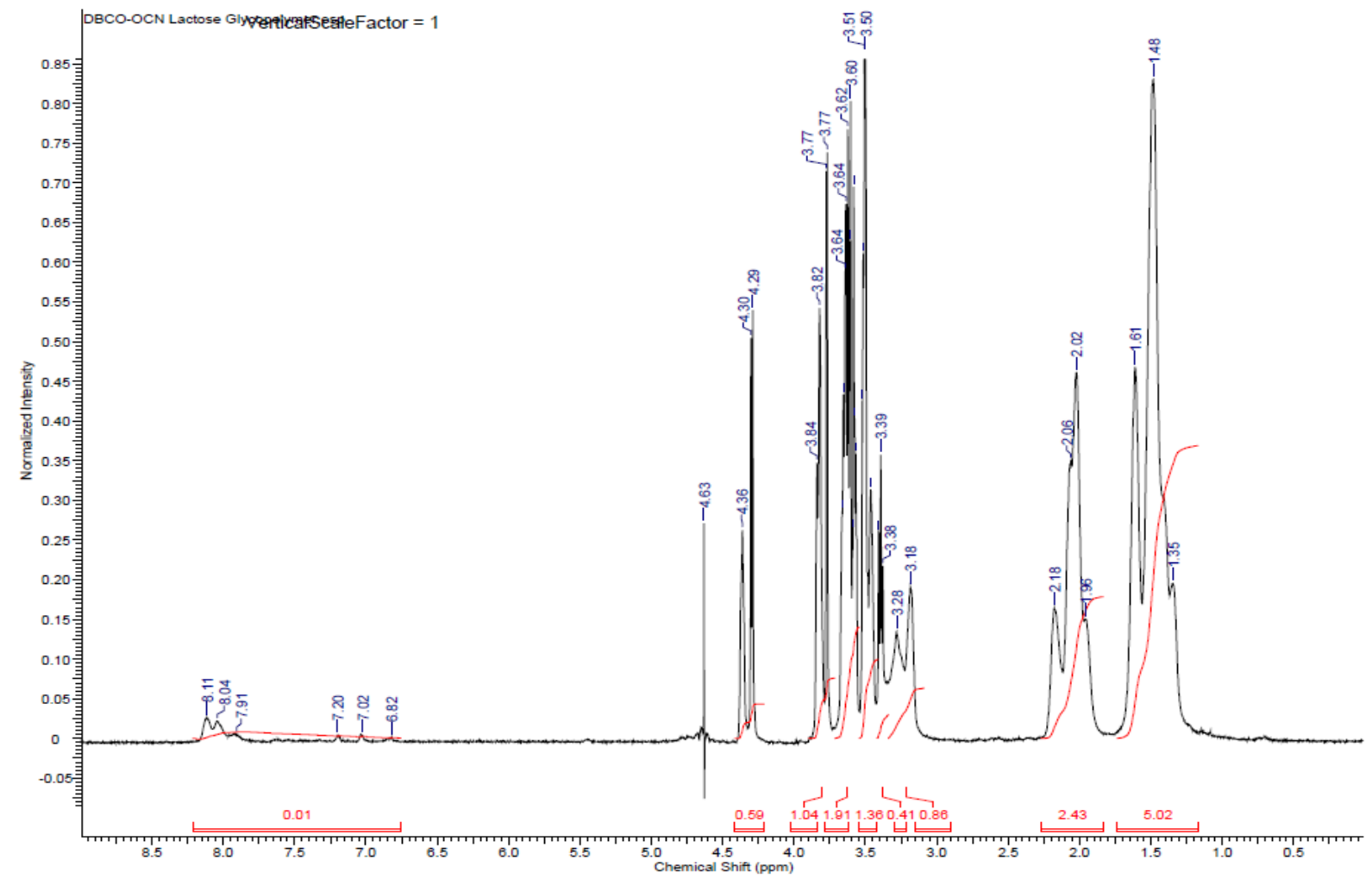

Figure 4s. ${ }^{1} \mathrm{H}$ NMR spectrum $\left(\mathrm{D}_{2} \mathrm{O}\right)$ of $\mathrm{DBCO}-\mathrm{PEG}_{4}$-glycopolymer

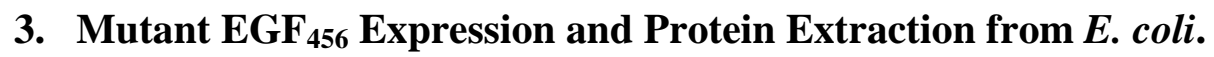


Recombinant $\mathrm{TM}_{456}$ was prepared by expressing plasmid $\mathrm{TM}_{456}$-Azide in E. coli methionine

auxotroph B834 (DE3) as described previously. ${ }^{[2]}$ Briefly, the expression plasmid $\mathrm{TM}_{456} \mathrm{GGM}$ was transformed into E. coli B834 (DE3) cells. The bacteria were grown at $37{ }^{\circ} \mathrm{C}$ in M9AA medium (1 L) supplemented with $1 \mathrm{mM} \mathrm{MgSO}_{4}, 0.1 \mathrm{mM} \mathrm{CaCl}_{2}, 0.4 \%$ (wt/v) glucose, $1 \mathrm{mg} / \mathrm{L}$ thiamine chloride, kanamycin $(35 \mathrm{mg} / \mathrm{L})$ and all proteinogenic amino acids. Upon reaching an $\mathrm{OD}_{600 \mathrm{~nm}}$ value between 0.8 and 1.0, exchange of medium was performed by centrifugation to remove methionine from the media. The cell pellet was then resuspended in $1 \mathrm{~L}$ of the M9AA medium without methionine and incubated at $37^{\circ} \mathrm{C}$ for $1 \mathrm{~h}$ to starve the cells followed by addition of $40 \mathrm{mg} / \mathrm{L}$ L-azidohomoalanine. Protein expression was induced with $0.5 \mathrm{mM}$ IPTG, and the culture was incubated at $25^{\circ} \mathrm{C}$ overnight. The His-rTM ${ }_{456}$-Azide was purified with Nickel column with eluent of $20 \mathrm{mM}$ Tris- $\mathrm{HCl}, \mathrm{pH} 8.0,300 \mathrm{mM} \mathrm{NaCl}$, and $250 \mathrm{mM}$ imidazole. A similar procedure was used for preparing positive control protein His-rTM 456 without incorporation of azide group.

\section{Site-Specific Galactose-modification of $\mathrm{rTM}_{456}$-Azide via Copper-Free Click Chemistry}

To $100 \mu \mathrm{L}$ of $20 \mathrm{mM}$ Tris- $\mathrm{HCl}$ buffer (pH 7.4) with $10 \mu \mathrm{g}$ of recombinant His-TM456-Azide, DBCO-PEG 4 -CONH-Phenyl-galactose $(1 \mathrm{mg})$ in $20 \mu \mathrm{L}$ DMSO was added, and the mixture was stirred for $12 \mathrm{~h}$ at room temperature. SDS-PAGE gel (12\%) was used to separate the reaction mixture, followed by glyco-staining and Coomassie blue staining to confirm reaction completion. Staining procedures were followed according to the manufacturers' instructions.

\section{Site-Specific Glycopolymer-Modification of $\mathrm{rTM}_{456}$-Azide via Copper-Free Click Chemistry}

To $100 \mu \mathrm{L}$ of $20 \mathrm{mM}$ Tris- $\mathrm{HCl}$ buffer (pH 7.4) with $10 \mu \mathrm{g}$ recombinant His-TM ${ }_{456}$-Azide, DBCO-PEG 4 -Glycopolymer (2 mg) in $20 \mu \mathrm{L}$ DMSO was added, and the mixture was stirred for $12 \mathrm{~h}$ at room temperature. SDS-PAGE gel (12\%) was used to separate the reaction mixture, followed by glyco-staining and Coomassie blue staining to confirm this reaction. Staining procedures were followed according to the manufacturers' instructions. 


\section{Protein C Activity Assay of rTM $_{456}$-Azide and its Galactose and Glycopolymer Conjugates}

The activity of recombinant $\mathrm{TM}_{456}$ was defined as moles of produced APC per min. by given amounts of $\mathrm{rTM}_{456}$ protein and $\mathrm{rTM}_{456}$ conjugates in the presence of thrombin. All activations of protein $\mathrm{C}$ by $\mathrm{rTM}_{456}$ conjugates were performed for $60 \mathrm{~min}$ in $20 \mathrm{mM}$ Tris- $\mathrm{HCl}$ buffer, $\mathrm{pH}$ 7.4, $100 \mathrm{mM} \mathrm{NaCl}, 0.1 \% \mathrm{BSA}$, and $5 \mathrm{mM} \mathrm{Ca}^{2+}$ at $37^{\circ} \mathrm{C}$. Typically, $20 \mathrm{nM}$ thrombin and different rTM concentrations $(1,1.5$, and $2 \mathrm{nM})$ were incubated in the assay buffer. After $60 \mathrm{~min}, 20 \mu \mathrm{L}$ antithrombin III $(3 \mu \mathrm{g} / \mu \mathrm{L})$ and $20 \mu \mathrm{L}$ heparin $(1000 \mathrm{IU} / \mathrm{mL})$ were added into the solution to stop the reaction. The inhibition of protein $\mathrm{C}$ activation was completed within $5 \mathrm{~min}$ at room temperature. The produced APC was measured through hydrolysis of a chromogenic substrate (Spectrozyme PCa) by comparing a standard curve, in which the concentration of APC to the rate of $p$-nitroanilide ( $p$ NA) formation was measured. The hydrolysis of Spectrozyme PCa was performed for $10 \mathrm{~min}$ in the assay buffer at $37^{\circ} \mathrm{C}$, in which $p \mathrm{NA}$ was produced and the concentration measured by monitoring at $\lambda=405 \mathrm{~nm}$ with a spectrophotometer.

\section{References}

[1] Hou, S.; Sun, X. -L.; Dong, C. -M.; and Chaikof, E. L. Bioconjugate Chem. 2004, 15, 954959.

[2] Zhang, H.; Weingart, J.; Jiang. R.; Peng, J.; Wu, Q.; Sun, S. -L. Bioconjugate Chem. 2013, 24, 550-559. 